\title{
Rebellion and Resistance
}

\author{
Claudia Mitchell
}

\section{$\cos 80$}

There is something rebellious about the work of Girlhood Studies so it is perhaps fitting that "Visual Disruptions" is the theme of this seventeenth issue of Girlhood Studies. The significance of 17 as an age in the life of girls and young women may vary, of course, across cultures, and, indeed, within contemporary popular culture in the West it is not necessarily seen as disruptive, as research on Seventeen magazine highlights. Nonetheless, we can think of the Janis Ian song from the 1970s, "At Seventeen," and the many songs from The Beatles to the Sex Pistols that refer to girls being 17, and contemplate a state that is far from compliant in relation to conventional femininity. The articles in this themed issue of Girlhood Studies, guest-edited by Danai S. Mupotsa and Elina Oinas, offer a fascinating investigation into the politics of girlhood and visual culture, and the politics of disruption itself. The contributions are also a testament to the close alliance between feminism and visual studies. As Joan Solomon so compellingly put it in the introduction to What Can a Woman do with a Camera? Photography for Women (1995),

[h] ow can we as women [and girls] tell stories that eradicate the disparity between how we are seen and what we feel? How do we present who we really are in terms of images? And why does it matter that we do? To answer this we need to understand the very fundamental way that the representation of people helps to determine who they become (2).

This book, published shortly after Jo Spence's death in 1994, along with her earlier Putting Myself in the Picture (1986) can serve as a reminder of the remarkable contributions she made to the study and practice of visual disruptions. While the visual has, of course, occupied an important place in previous issues of Girlhood Studies (from articles on the uses of photovoice, video, drawing, and digital storytelling in participatory research, to the analysis of movies, TV shows, and graphic novels, as well as the inclusion of visual essays), Mupotsa and Oinas take us into a new arena where, as they 
note in their introduction, images are seen to "unsettle, disrupt, disqualify, and transgress the visual and affective expectations visited upon contemporary girls." Above all, the articles and reviews, and the themed issue taken as a whole, establish the notion of disruption (and especially visual disruption) as a key feature of Girlhood Studies.

\section{References}

Spence, Jo, and Joan Solomon. 1995. What can a Woman Do with a Camera? Photography for Women. Melrose, TN: Scarlett Press.

Spence, Jo. 1986. Putting Myself in the Picture. London: Camden Press. 